\title{
RISKS IN BUILDING CONSTRUCTION AND ATTENDANT MANAGEMENT STRATEGY (IN UYO METROPOLIS, AKWA IBOM STATE, NIGERIA)
}

\author{
Francis P. UDOUDOH (Ph.D, RSV) ${ }^{1}$ and Usen P. UDOH (Ph.D, FNIA) ${ }^{*}$ * \\ ${ }^{1}$ Dept of Estate Management, University of Uyo, Akwa Ibom State \\ Tel.: 08062516484 \\ 2*Department of Architecture, University of Uyo, P.M.B. 1019, Uyo-Nigeria \\ Tel.: 08035490104
}

https://doi.org/10.37602/IJSSMR.2020.3418

\begin{abstract}
Risk is inherent in building construction; and at every stage of the construction process, the burden is forced with the daunting task of mitigating the identified risk. This study seeks to examine the causes of risk in building construction as well as identifying the appropriate management strategies for mitigating the risk. The questionnaire was prepared and administered on a total of 36 persons found in twelve (12) project sites visited in Uyo, Akwa Ibom State. In each site, three (3) persons including property owners, site engineers/property managers, builders/masons, carpenters, electricians, plumbers and town planning officers were randomly picked for the administration of questionnaires. Out of the sampled 36 persons, 32 persons which represented $88.89 \%$ completed the questionnaires and returned same to the researcher within the timeframe. This constituted the sample size for the study. The major causes of risks in building construction were identified as poor soil texture which resulted to poor setting and timbering as shown by building construction index (BCI) of 0.88 , poor concrete mix for blocks and choking as shown by BCI of 0.88 and foundation as shown by BCI of 0.72 , use of inferior building materials as shown by BCI of 0.72 , and poor workmanship as shown by BCI of 0.72 . The research revealed that the key elements in risks management process revolve around proper supervision of the project which involves identification and evaluation of risk sources, adequate choice of building materials and workforce, and monitoring of physical construction. It recommended routine inspection to identify potential sources of risks and properly management to forestall unforeseen occurrences in the building.
\end{abstract}

Keywords: Risk, building construction, risk appraisal, management strategy, project supervision.

\subsection{INTRODUCTION}

Risk is inherent in each project within the construction industry in different forms and occurs at different stages of construction including site selection, design and setting out before the 


\section{International Journal of Social Sciences and Management Review}

main building construction. The process of building development falls into six (6) major stages, namely, site acquisition, preparation of development plans, sourcing for finance, building construction, provision of estate infrastructure, and estate management (Udoudoh, $2016 \& 2018$ ). The actual building construction process involves excavation and trench timbering, concrete operations, wall construction, roofing, fitting of doors and windows, electrification, water services and sanitary plumbing, then finishing. Finishing embodies internal and external rendering and painting. Bakara et al (2019) identified the project phases as initiation, planning, execution, monitor and control, and closure; with attendant risks occurring at any phase. The occurrence of risks in project construction is consequential upon poor topography, building technology and materials, construction process and project supervision.

The construction industry is the main driver of urban physical development and economy as it is supported by conduct of feasibility studies, project design, cost estimation, construction and maintenance services. Ideally, the goal of any investor is to embark on a project or scheme that involves minimum risks. According to Bakara et al (2019), uncertainty (which is always translated into risks because both are causing events with a probability of less than $100 \%$ ) may come from the undefined scope, undefined project objectives, project constraints, improper design, ambiguous contract and other unknown policies. Risks at project sites emanate from several sources which are categorized into internal and external sources. The internal sources are those the project manager can control which often emanate from project sites, construction technology and other human factors; while external sources are outside the project manager control such as economic conditions, political conditions, legal, natural hazards, social conditions. These factors constitute threats with attendant negative impact on the project execution. The impact of risk on project development has forced many investors to adopt wrong development strategies which result in poor construction leading to collapse of several buildings and structures in different urban centres of Nigeria. Since risk is a common feature of all forms of investment, the process of its management is considered the main stay of building construction process.

Studies on risk management revolve around using the right team of professionals (skilled and unskilled) in construction industries with relevant training and experience in building construction. Risk management is the process of identification, analysis and acceptance or mitigation of uncertainty in investment decisions (Kenton, 2020). In relation to project development, it is a collaborative effort aimed at driving the project to the targeted goal through the process of identifying and evaluating the project at different stages with the aim of mitigating any risks that may cause harm to workers, damages to property, the project site and the surrounding environment.

Risk management starts with identification of the potential risk, measuring the extent of the impact on the project and deciding on how to control it. Risk identification requires proper classification of the types of risk, carrying out in-depth analysis and its implications on the project, and projecting into the future. According to Ubom (2011), upon identification of risk, the next step is to measure or quantify them using either the average (or mean) absolute deviation or standard deviation. The higher the standard deviation, the higher the risk involves and vice versa. Risk identification and measurement are undertaken to enable the project manager to select appropriate risk management approaches. The techniques and 


\section{International Journal of Social Sciences and Management Review}

processes that may be applied to manage the identified risk elements are either proactive or reactive (Bakara et al, 2019). The difference between proactive and reactive depends on the time of managing the identified risk. Thus, if the risk is managed before its occurrence, it is a proactive approach; but if it is managed after the occurrence, it is a reactive approach.

Risks in construction projects cannot be averted due to the involvement of diverse skills and people in the coordination of a vast amount of complex and interrelated activities (Ogwueleke and Udoudoh, 2017). Most construction projects fail due to the inability of the construction team to identify involved risks and also assess their impact on project performance (Luka and Muhammad, 2014). This is why risk management should commence with identifying and recording the risk elements at different stages of project construction; then assessing the likelihood of their occurrence and what the consequences would be. Ekong (2019) noted that the task of risk management includes identification, monitoring, prevention, mitigation and risk transfer, and preparation for attending to recovery and reconstruction from damages caused by emergencies and disasters. She outlined the key elements in the risks management process as a chain which commence with identification of risks, measurement of risks, evaluation/assessment of risks, preparation of management/strategic plan, implementation of the management plan and review of the process from time to time to reflect current challenges. PMI (2017) identifies six (6) processes in the course of managing risk, viz, planning risk management, risk identification, qualitative risk assessment, quantitative risk assessment, plan risk response, and monitor risk.

One fundamental problem in building construction is how many investors embark on projects without carrying out a careful examination to identify and assess potential sources of risks inherent in the projects which will enhance adopting appropriate management strategies. According to Creedy, Skitmore and Wong (2010), risk assessment is critical for establishing an efficient cost estimating improvement system that can be used to benchmark areas of potential problems thereby checkmating cost overrun. Risk management is aimed at determining the probable events and impact of occurrence on the projects. According to Piekara (2019), taking a holistic approach to identifying the types of risks and managing it does not only enable the project team to alleviate risks but anticipate and plan for prospective challenges. The focus is on risk minimization but not on elimination. This is because no matter how well the risk is managed, it can never be totally eliminated.

This study is based in Uyo Metropolis, the capital of Akwa Ibom State. In recent times, the city has been likened to a "Construction Site" due to the massive construction work occurring within the City. However, previous reports (Udoudoh 2016) have also shown the enormity of risk associated with building construction in the area. This study aimed at generating knowledge on the potential sources of risk as well as suggesting appropriate risk management strategies while embarking on building construction to forestall unforeseen occurrences in the area.

\subsection{OBJECTIVES OF THE STUDY}

The specific objectives of this study include

I. to identify and examine the causes of risk in building construction (in the study area) 


\section{International Journal of Social Sciences and Management Review}

II. to identify the Management strategies appropriate for mitigating risk in building construction ( in the study area)

\subsection{CONCEPTUAL FRAMEWORK FOR RISK IDENTIFICATION AND APPRAISAL IN BUILDING CONSTRUCTION}

It has already been recorded that risk emanates from several sources which are categorized into internal and external sources. The categorization of identified risks helps to determine their root causes; thus enabling the project team to develop mitigation approaches to address their occurrence. The risk sources are peculiar task before project appraisers in their preparation of development appraisal. The examination of these potential risk sources is fundamental to sustainable building construction.

a) Technological Risk: Availability of good quality construction materials and techniques to install them constitutes major threats to the building industry in Nigeria. More so, the advent of new technology comes with the introduction of new building materials with prescriptions for measurement, mixture and usage. The builders and engineers at sites are expected to study these materials to know how, where and the quantity to use at different places and purposes. Where they are not properly used, there is a tendency of building failure in the nearest future.

b) (b) Environmental Risk: Environmental risks are disasters that affect physical development, human lives, as a result of actions and inactions of man and some natural phenomenon. Typically, are terrain and soil texture which have severe cost implications on the project. They affect the design of the building, conveyance of building materials and workers to and fro project sites in the coastal region. The other risks occur byways of environmental pollution, land degradation, flooding, soil erosion and atmospheric contamination. The occurrence may come naturally or through human activities.

c) Physical Risk: This occurs as a consequence of upsurge in urban growth and expansion, which result in certain buildings becoming obsolete in terms of location, design, building materials and technology that were used in construction. Where this happens, such buildings may no longer be suitable at their original locations thus requiring relocation or change of use that requires additional financial implications.

d) Economic Risk: The economic situation of a community, region or the nation, in general, affects building construction vis-à-vis subsequent market situation. This may be caused by non-availability of development funds, fluctuation in prices of building materials, variation in the cost of labour, and change in management policy or review in rental income. Economic risk has both positive and negative impact on project development which reflects the uncertainty of cash outflow by an inflow to real estate investor.

e) Timing Risk: The question of timing has a serious bearing on building construction. Experience has shown that appropriate timing enables the best-conceived project to be executed and delivered at the most appropriate time with the least risks encountered. Where the development site was acquired through the site and service scheme or in 


\section{International Journal of Social Sciences and Management Review}

the public estate, the lease stipulates the timeframe within which the beneficiary is expected to complete the project. Apart from this, if the project was developed with equity funds, it needs to be completed on scheduled for the developer to commence operation, thus being able to refund the borrowed capital to the funding institution timely as agreed.

Risk appraisal or analysis is a basic aspect of any project development which enhances the quality of the envisaged or on-going project. It is an integral part of any project development as it is the desire of every developer or investor to realize the project goal with less risk. In the opinion of Chinneck (2000), the evaluation of project risk depends on two basic principles: the appraiser's ability to identify and understand the nature of variations and the possibilities surrounding the key project variables; and the application of adequate tools and techniques to process implications of the risk on the project's returns. The techniques used for risk analysis depend on the quality and quantity of data and information available to the project appraiser or analyst; thus, the adopted appraisal methods can be qualitative or quantitative. The qualitative analytical technique is adopted when the level of risk is minimal and numerical data available are not adequate for a detailed quantitative analysis. It requires the application of the questionnaire, interviews, discussions, evaluation of specialists and experts' opinions. One can then say that qualitative analysis is based on professional judgment, experience and initiative. The quantitative appraisal techniques are used when circumstances require taking financial investment decision that will enhance appropriate capital utilization. The application of risk analysis for project development has been documented by many scholars, including Savvides (1994), Ajayi (1998), Ogbuefi (2002), Ogunba (2013) and Udoudoh (2016). The application of Capital Investment Appraisal Techniques (CIAT) justifies the basis of capital injection on projects.

An appraisal of a proposed project is carried out to determine the worthwhileness of a contemplated or an on-going project to ensure its feasibility and/or viability. Going by this, the residual valuation technique lent itself as a selector of the highest and best use of land for a particular project. The technique estimates the maximum purchase price of a chosen site by deducting the expected total cost of development, including allowances to cover risks and profits from the expected sale of the completed project. Cost Benefits Analysis (CBA) is used to assess the desirability of projects which are likely to have an impact on the host communities and the public in general. The technique helps to determine which investment alternative is likely to provide the greatest return to the investor. Payback Appraisal technique is used to select the project that would take the shortest length of time to recover the capital investment. The technique is most useful in a project site characterized by high economic and political instability or risk. Cash flow appraisal technique requires adequate computation to be able to derive expected inflows and outflows for the investment by applying either the internal rate of return (IRR) or external rate of return (ERR) in the computations (Udoudoh, 2017).

Other appraisal techniques such as performance measurement are applied to analyze the effectiveness of unit decision, degree of compliance to building plans and regulations, and management strategies to ameliorate risk elements. The technique allows resource managers to check progress and to confirm results. The appraiser can also use sensitivity analysis to determine what the outcome of another appraisal would be, assuming he ignores certain 


\section{International Journal of Social Sciences and Management Review}

factor elements that do not have a direct impact on the project and only concentrate on those ones that are likely to serious impact on the construction. Ogunba (2018) listed those variables influencing total development cost (of the project) to include demolition cost, construction cost, landscaping, building period, the interest rate on finance, amongst others. The application of scenario analysis in risk adjustment came to fore as an extension of sensitivity analysis. The idea behind it is to establish management strategies which can minimize risks and uncertainties. It recognizes that the occurrence of a change in one variable may likely affect other variables. Simulation becomes necessary when any attempt is made to systematically introduce probability into the sensibility analysis framework. Monte Carlo simulation adds the dimension of dynamic analysis to project evaluation by making it possible to build a random scenario which is inconsistent with other analysts' key assumptions about risk.

A risk analysis application utilizes a wealth of information, be it in form of objective data or experts' opinions, to quantitatively describe the uncertainty surrounding the key project variables as probability distributions, and to calculate in a consistent manner its possible impact on an on-going project. The outcome of risk analysis is the total contributions from all possible stakeholders to achieve the expected project result. Where the project risk appraisal is properly carried out, the prospective developer is provided with a complete risk profile of the project from foundation to occupation, showing all the possible means of managing discovery risks at every construction stage.

\subsection{MATERIALS AND METHODS}

\section{i. Sample / Data Collection}

Since building collapse has become a common occurrence in different parts of Nigeria, we found it necessary to interview stakeholders in the building construction industry to uncover the causes of risks that led to such casualties. The questionnaire was prepared and administered on a total of 36 persons. Out of the sampled 36 persons, 32 persons which represented $88.89 \%$ completed the questionnaire and returned same to the researcher within the timeframe. This constituted the sample size for this study. Twelve (12) project sites were visited in Uyo Urban, and in each, three (3) persons found at sites were administered the questionnaire to complete. Those chosen for questionnaire administration included property owners, project/site managers, builders/masons, artisans and town planning officers. The questionnaire was to identify the major sources and causes of risks in building construction and how to ameliorate the identified risks.

The sampled population of thirty-two (32) persons selected in the building sites included property owners, site engineer/project managers, masons, artisans and town planning officers. The breakdown is shown in Table 1 below:

Table 1: Administration of Questionnaire

\begin{tabular}{|l|l|c|c|}
\hline S/N & Respondents & Population & Frequency \\
\hline 1. & Property Owners & 4 & 12.50 \\
\hline
\end{tabular}




\section{International Journal of Social Sciences and Management Review}

Volume: 03, Issue: 04 "July - August 2020"

ISSN 2582-0176

\begin{tabular}{|l|l|r|r|}
\hline $\mathbf{2 .}$ & Site Engineers/Project Managers & 8 & 25.00 \\
\hline $\mathbf{3 .}$ & Builders/Masons & 14 & 43.75 \\
\hline 4. & Other Workers (artisans) & 4 & 12.50 \\
\hline $\mathbf{5 .}$ & Planning Officers & 2 & 6.25 \\
\hline & Total & $\mathbf{3 2}$ & $\mathbf{1 0 0 . 0}$ \\
\hline
\end{tabular}

Source: Authors' field survey (2020).

During the collation, it was discovered that majority of persons that completed the questionnaire and returned were 14 builders/masons which represented $43.75 \%$ and followed by 8 site engineers/project managers which represented $25 \%$ of the sampled population. On two (2) project sites, we stumbled on town planning officers who were on their routine inspection exercise and they happily collected and filled the questionnaires for us as shown in Table labove.

\section{ii) Data Analysis / Procedures for computing the Building Construction Index (BCI)}

There are five (5) major stages in building construction and each stage has some peculiar causes of risks which we seek to identify. The respondents were requested to rate the causes of building collapse using Likert scale; ranging from very serious cause with a weight value of 5 , serious cause (4), mild cause (3), no cause (2) to undecided with weight value of 1 . The total weight value (TWV) calculated for each of the identified cause was arrived at from the summation of products of the number of responses for rating of each variable and the respective weight value for each rating. The building construction index (BCI) was then calculated as a ratio of TWV to the maximum weight value. A cut-off score of BCI computed was determined by summing the nominal weights and dividing by the total number of weighted items and highest weight respectively: $(1+2+3+4+5) / 5 / 5=0.60$. Thus, the causes that have BCI higher than 0.70 were defined as significant, those with BCI above 0.60 but less than 0.70 as moderate, while those less than 0.60 as insignificant. The approach adopted from Udoudoh and ujeni (2015) is with the expectation that the adoption of 0.60 as reference value will effectively cover only important causes of risks in terms of their impacts on building construction.

\subsection{FINDINGS}

\section{i. Causes of Risk in Building Construction (in the study area)}

Table 2: MAJOR CAUSES OF RISK IN BUILDING CONSTRUCTION

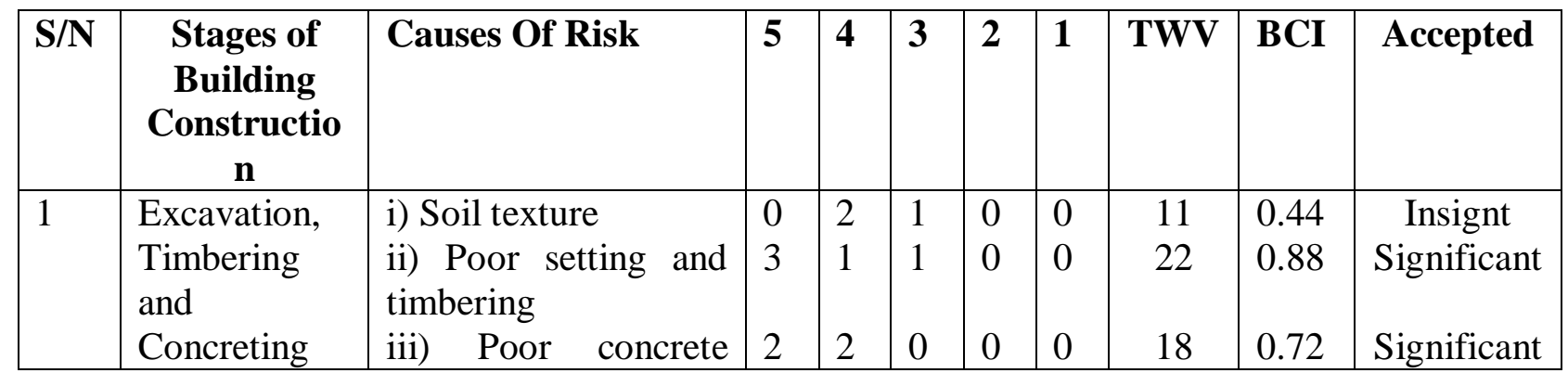




\section{International Journal of Social Sciences and Management Review}

Volume: 03, Issue: 04 "July - August 2020"

ISSN 2582-0176

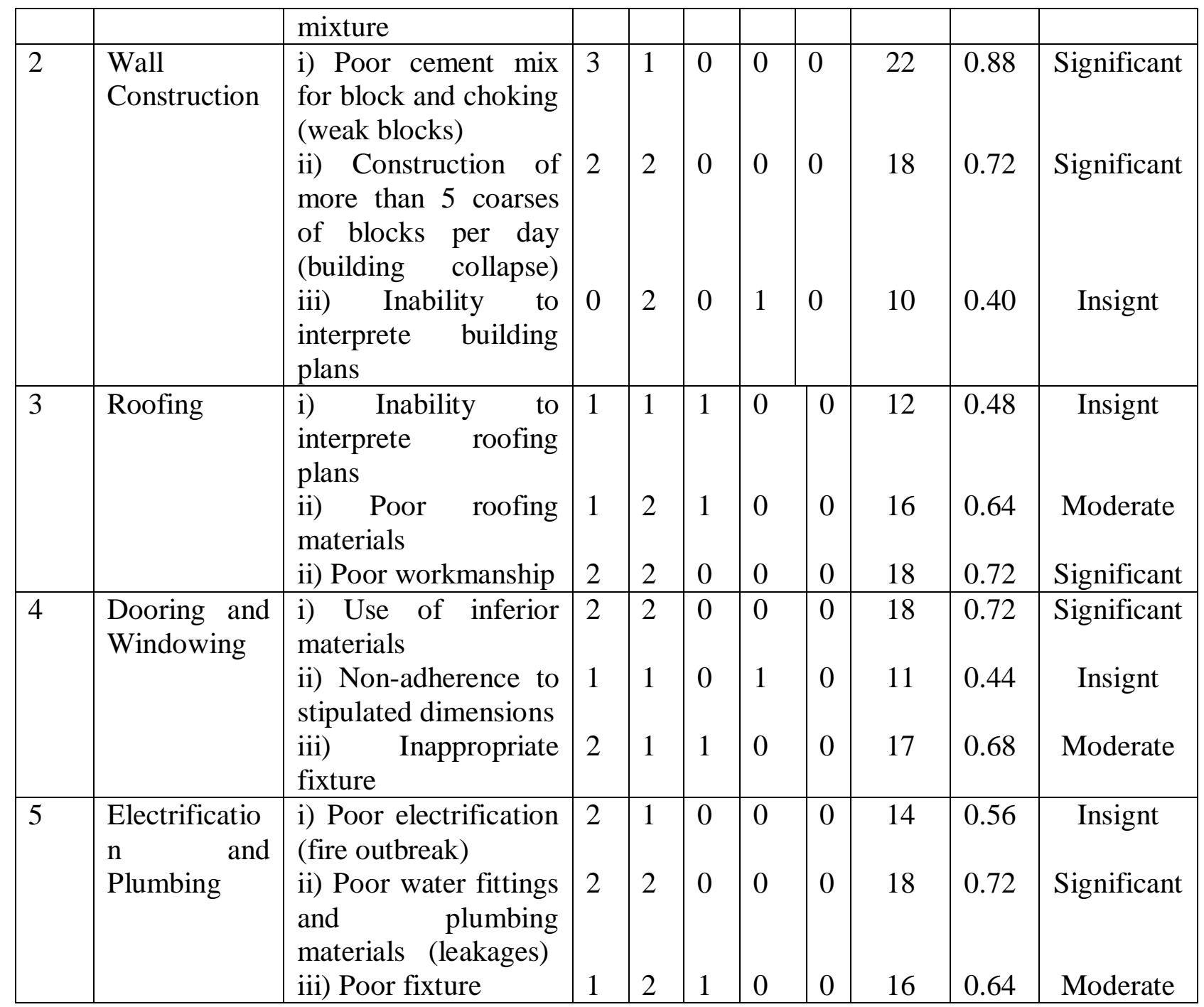

Fieldwork by Researchers (2020)

As shown in Table 2, each stage of construction has some identified causes of risk. What we did was to accept those risks' causes with building construction index (BCI) above 0.70 as significant causes of risk while those below 0.70 but above 0.60 as moderate causes with serious impact on the construction. They were accepted as major causes of risks in building construction. The major cause of risks in building construction that leads to building collapse was identified to be poor soil texture that led to improper setting and timbering. This was followed by a poor concrete mix used for moulding blocks and choking of the blocks on the walls. The poor concrete mix also affected the foundation cast for the building hence low load-bearing capacity. The use of inferior building materials also resulted in building construction risks. Those with BCI of less than 0.60 were rejected because their impacts on the construction had no significant impacts.

\section{ii. Management of Risks in Building Construction}




\section{International Journal of Social Sciences and Management Review}

Volume: 03, Issue: 04 "July - August 2020"

ISSN 2582-0176

Thereafter, respondents were requested to indicate the strategies that should be adopted to control the identified risk sources. This is shown in Table 3 below:

Table 3: Management of construction Risks

\begin{tabular}{|c|c|c|c|}
\hline $\mathbf{S} / \mathbf{N}$ & $\begin{array}{lll}\text { Causes of } & \text { Building } \\
\text { Collapse } & & \end{array}$ & BCI & Management Strategy \\
\hline 1. & Poor setting and timbering & 0.88 & $\begin{array}{l}\text { i) Good Knowledge of soil texture } \\
\text { ii) Using experienced builders for } \\
\text { pegging and timbering } \\
\text { iii) Adequate supervision }\end{array}$ \\
\hline 2. & $\begin{array}{l}\text { Poor Concrete mix for } \\
\text { blocks molding } \\
\text { choking }\end{array}$ & 0.88 & $\begin{array}{l}\text { i) Good concrete mixture } \\
\text { ii) Rendering and painting } \\
\text { ii) Adequate supervision }\end{array}$ \\
\hline 3. & $\begin{array}{l}\text { Poor concrete mix for } \\
\text { foundation }\end{array}$ & 0.72 & $\begin{array}{l}\text { i) Good concrete mixture } \\
\text { ii) Damp proof course } \\
\text { ii) Adequate supervision }\end{array}$ \\
\hline 4. & $\begin{array}{l}\text { Construction of more than } \\
5 \text { coarses of blocks/day }\end{array}$ & 0.72 & $\begin{array}{l}\text { i) Good concrete mixture } \\
\text { ii) Rendering and painting } \\
\text { iii) Adequate supervision. }\end{array}$ \\
\hline 5. & Poor roofing work & 0.72 & $\begin{array}{l}\text { i) Use of good and experienced } \\
\text { carpenters } \\
\text { ii) Adequate supervision }\end{array}$ \\
\hline 6. & $\begin{array}{l}\text { Use of inferior materials } \\
\text { for doors and windows }\end{array}$ & 0.72 & $\begin{array}{l}\text { i) Use of appropriate materials } \\
\text { ii) Adequate supervision }\end{array}$ \\
\hline 7. & $\begin{array}{l}\text { Poor materials for water } \\
\text { fitting and plumbing }\end{array}$ & 0.72 & $\begin{array}{l}\text { i) Use of appropriate plumbing } \\
\text { materials } \\
\text { ii) Adequate supervision }\end{array}$ \\
\hline 8. & $\begin{array}{l}\text { Inappropriate fixture of } \\
\text { doors and windows }\end{array}$ & 0.68 & $\begin{array}{l}\text { i) Use of good and experienced } \\
\text { carpenters } \\
\text { ii) Adequate supervision }\end{array}$ \\
\hline 9. & Poor roofing materials & 0.64 & $\begin{array}{l}\text { i) Use of appropriate roofing materials } \\
\text { ii) Adequate supervision }\end{array}$ \\
\hline 10. & Poor plumbing work & 0.64 & $\begin{array}{l}\text { i) Using good and experienced } \\
\text { plumbers } \\
\text { ii) Adequate supervision }\end{array}$ \\
\hline
\end{tabular}

Source: Authors' field survey (2020).

Table 3 applied the total weight values (TWVs) and building construction indices (BCIs) which were computed in Table 2 . The most significant cause of building construction risk was identified to be poor soil texture which led to improper setting and timbering of the trenches for foundation. To alleviate this problem, experienced builders/masons with adequate knowledge of pegging and timbering should be employed while the site engineer provides a proper supervisory role to guarantee perfection. To forestall the negative effects of using the poor concrete mix to mold blocks, and cast foundation that is below the loadbearing capacity of the building and strength of walls, the builder should introduce damp 


\section{International Journal of Social Sciences and Management Review}

proof course after foundation while the walls need to be rendered and painted to improve their strength. The services of trained and experienced block molders, masons and builders are required for these purposes. Similarly, the services of trained and experienced carpenters, electricians and plumbers are necessary for roofing, electrification and plumbing. The respondents all agreed that supervision by the appropriate officer is inevitable at every stage of the project as construction work progresses. Adequate supervision stamps out the use of poor building materials and inexperienced workforce in the construction exercise, thereby reducing greatly the sources of risks in the building.

\subsection{DISCUSSION OF FINDINGS}

This research has shown that building construction process is in phases which require a consortium of professionals to execute their roles according to specifications that will ensure smooth project execution. At every stage of the construction, there are risk elements and appropriate measures to ameliorate the identified risks. The identified risks causes include poor soil texture, poor concrete mix for foundation and choking of blocks, use of inferior building materials, inexperienced workforce, and laxity in the supervision of the construction work. At the foundation stage, there are problems associated with the soil texture that requires the builder having adequate knowledge that will help in excavation, timbering and casting of a solid foundation. The construction of the walls requires experienced and trained block moulders, masons and building technologists. Where the need arises, re-enforcing the concrete mix at specific points may be done to carry the load-bearing of the superstructure; while columns and beams should be introduced at appropriate points in the building. The site engineer or project manager should be persons with enough skills to interpret the building drawings and plans which the builders/masons, carpenters, electricians, plumbers and other workers will follow. Strict compliance with the building drawings and plans requires closed supervision of the project at every stage by the site engineer or project manager. This means that it is risky for the supervisor to abandon his project sites when construction is on-going.

\subsection{CONCLUSION AND RECOMMENDATIONS}

Each member of the building team is engaged in separate aspects of the construction. While executing their works, they are bound to identify risk sources, plan and develop mitigation approaches to address them. The training of artisans in construction industry should be more formal and possession of skills acquisition certificates made a qualification for recruitment at project sites (Udoudoh, 2018). This is necessary as each member of the construction team can impact on the project, contribute to risk and profess to it mitigation. It is pertinent to point out that all identified risks do not impact on the project equally. Therefore, the risk that has a high likelihood of occurrence and that would have high impact on the building construction requires more risk mitigation strategy than one that is less likely to occur, or will have a lower perceived impact on the project.

From the data presented and analyzed above, the most significant cause of risks in building construction that lead to building collapse is poor soil texture that led to improper setting and timbering. This was closely followed by the use of poor concrete mix which leads to casting of poor foundation and strength of walls. In support of Akpabio (1997), Udoh and Unyanga (2013), the choice of materials and methods of construction for walls, roofs, ceilings, doors 


\section{International Journal of Social Sciences and Management Review}

Volume: 03, Issue: 04 "July - August 2020"

ISSN 2582-0176

and windows should be guided by the need for security of the building. This makes it inevitable to use durable and recommended materials in the building construction. On the whole, it is recommended that identified risks should be timely and properly managed to forestall unforeseen occurrences in building.

\section{REFERENCES}

Akpabio, M. J. (1997). The Complete Guide to Building a House. Modern Business Press Ltd, Uyo.

Ajayi, C. A. (1998). Property Investment Valuation and Analysis. De-Ayo Publications, Ibadan.

Baraka, H.; Kotb, M. H. \& Abu-Dief, M. I. (2019). Risk in Construction Industry. PM World Journal, www.pmworldjournal.com VIII(IV) May, 1 - 6.

Ekong, F. (2018). Integration of Risk/Disaster Management in Urban and Regional Planning.

Uyanga, J. \& Ekong, F. (Eds). Urban Crises and Management: Sustainable Planning Approaches. Dept. of Urban and Regional Planning, University of Uyo. Pp 16 - 35.

Chinneck, J. W. (2004). Practical Optimization: A Gentle Introduction. Online Textbook. http://www.sec.carleton.ca/faculty/chinneck/po.html.

Creedy, G. D; Skidmore, M. \& Wong, J. K. W. (2010). Evaluation of Risk Factors leading to Cost-overrun in delivery of Highway Construction Projects. Journal of Construction Engineering and Management. 136(50, 528-537.

Kenton, W. (2010). Risk Management in Finance. Investopedia. www.Investopedia.com/ters/risk.

Luka, G. T. \& Mohammad, S. I. (2014). Evaluating the Impact of Risk Factors on Construction Projects in Nigeria. International Journal of Engineering Science. 3, 10 15.

Ogbuefi, J. U. (2002). Aspects of Feasibility and Viability Studies. Institute for Development Studies, University of Nigeria, Enugu Campus, Enugu.

Ogunba, O. A. (2013). Principles and Practice of Property Valuation in Nigeria. Atlantis Books, Ibadan.

Ogunba, O. A. \& Ajayi, C. A. (2018). Property Feasibility and Viability Studies. Obafemi Awolowo University Press, Ile-Ife.

Ogwueleka, A. C. \& Udoudoh, F. P. (2017). The Impact of Risk and Reward Dynamics in Incentive Compensattion Plans in the Nigerian Construction Industry. International Journal of Constuction Management (Taylor \& Francis Group) Pp1 - 13. 


\section{International Journal of Social Sciences and Management Review}

Volume: 03, Issue: 04 "July - August 2020"

ISSN 2582-0176

Piekara, E. (2019). Managing Risk to Raise Project Performance. PM World Journal, www.pmworldjournal.com VIII(IV) April, 1 - 6.

PMI (2009). Practice Standard for Project Risk Management. Project Management Institute. PMBOK $®$ Guide - 6th Edition.

Savvides, S. C. (1994). Risk Analysis in Investment Appraisal. Project Appraisal. 9(1), 3 18.

Ubom, U. (2010). The Perspective of Risk Management: Domestic and International. Journal of Administrative Sciences. 1(1), 172 - 184.

Udoh U. and Uyanga, J. (2013), Housing Conditions and Health in Rural Nigeria: A Case Study of Akwa Ibom State. Research On Humanities And Social Science,IISTE USA 3 (18): $34-41$

Udoudoh, F. P. (2016). Evaluation of Risk Elements in Real Estate Investment in Nigeria: The Case of Uyo Metropolis, Akwa Ibom State. IQSR Journal of Business and Management (IQSR); 18 (10), Ver. 11.70 - 75.

Udoudoh, F. P. (2017). A Review of Urban Infrastructure Project Appraisal Techniques in Uyo, Nigeria. Emerging Issues in Urban Land Use and Development in Nigeria. (Eds)

Nuhu, M. B; Ajayi, M. T. A; Olatunji, I. A. \& Udoekanem, N.B., Dept. of Estate Management, Fed. University of Tech, Minna. (August), pp177 - 190.

Udoudoh, F. P. (2018). Promoting Entrepreneuship and Capacity Building in Real Esatate Development in Nigeria. Building Capacity for Self Reliance: Entrepreneuship and Environmental Development. Proceedings of International Conference, Faculty of Environmental Studies, University of Uyo 